\title{
Dietary requirements of individual nectar foragers, and colony-level pollen and nectar consumption: a review to support pesticide exposure assessment for honey bees
}

\author{
Sara RodNEY ${ }^{1}$, John PURdY ${ }^{2}$ \\ ${ }^{1}$ Intrinsik Corp, 208-2120 Robertson Rd., Ottawa, ON K2H 5Z1, Canada \\ ${ }^{2}$ Abacus Consulting Services Ltd, 8725 Twiss Road, P.O. Box 323, Campbellville, ON L0P 1B0, Canada
}

Received 6 December 2018 - Revised 21 June 2019 - Accepted 16 September 2019

\begin{abstract}
Exposure to pesticides is a potential concern for pollinators that may forage on plants containing residues. A key element of estimating dietary risk to pollinators is to determine the nature and amount of food consumed by individuals. Recent efforts have focused on honey bees (Apis mellifera), of which nectar foragers are thought to be at greatest risk of dietary exposure due to their foraging behavior and high energy requirements for the flight-foraging activities. At upper tiers of pesticide risk assessment for honey bees, field studies with whole colonies are carried out to gauge effects of expected exposures; however, without knowing how much nectar and pollen is being consumed by colonies and the potential variability in these parameters, it is difficult to accurately assess risk under other untested exposure scenarios. The objective of this review was to collate available data from the literature regarding (1) the quantity of nectar required by nectar foragers and (2) the quantities of nectar, pollen, and supplements that are consumed by colonies; the purposes being to develop a database that can be used to improve exposure and risk assessments, and to identify data gaps for further research. A number of studies investigating honey bee energetics have been identified that can be used to estimate sugar requirements for foragers under different conditions (e.g., resting, flying). A few more recent studies have been able to quantify the amount of time foragers spend outside the hive. Factors requiring further investigation include levels of energy expenditure while outside the hive, and the sugar content of available nectars, which may also affect foraging behavior. At the colony level, data on food consumption are sparse and primarily anecdotal. Colony size, management, and location seem to be major factors contributing to differences in nectar foraging and honey production. Further research is needed to better quantify and predict colony use and storage of food resources.
\end{abstract}

\section{Apis mellifera / honey bee / diet / nutrition / energetics / forager}

\section{INTRODUCTION}

Quantifying food ingestion is a key component of estimating exposure of animals to pesticides through the diet (USEPA 1998; USEPA 2011).

Electronic supplementary material The online version of this article (https://doi.org/10.1007/s13592-019-00694-9) contains supplementary material, which is available to authorized users.

Corresponding author: J. Purdy, john@abacuscsl.com Handling editor: Cedric Alaux
Honey bees (Apis mellifera L.) rely on two primary food resources, pollen and nectar. Generally speaking, pollen provides the protein and essential amino acids necessary for development, and nectar provides the carbohydrates necessary to meet energy needs. Determining food consumption for honey bees is complex because (1) nutritional needs are highly variable among and within different castes and life stages; (2) mixing, modification, storage, and sharing of collected foods occurs among honey bees; (3) there is inter- and intra-seasonal variability in food availability and energy requirements; (4) 
beekeeping practices, including supplemental feeding, are highly variable; and (5) colony size, health, and genetics affect foraging.

The standard method of risk assessment for honey bees and other pollinators potentially exposed to pesticides begins with a highly precautionary screening assessment (e.g., Tier 1). The goal is to identify potential risk scenarios that require more complex testing and assessment to better understand risk in subsequent tiers. Initial screening is based on laboratory tests of lethal and sublethal effects involving individual bees. Higher tier assessments for honey bees require colony-level effects testing (Tiers 2 and 3; USEPA et al. 2014). In their guidance for assessing risk to pollinators from dietary exposure to pesticides, the United States Environmental Protection Agency (USEPA), Canadian Pest Management Regulatory Agency (PMRA), and California Department of Pesticide Regulations (CDPR) begin, in their first tier of assessment (Tier 1), with deterministic estimates of food ingestion for honey bees (USEPA et al. 2014). For nectar foragers, which are expected to consume the highest amounts of nectar, the guidance recommends the use of a median of $292 \mathrm{mg}$ nectar/bee/day in risk assessment (pollen ingestion by nectar foragers is negligible in this context; Online Resource 1; USEPA et al. 2012, 2014). This nectar ingestion rate put forward by the Agencies is based on a Monte Carlo simulation that was conducted with probabilistic estimates of number of trips per day, trip duration, sugar required for flight and resting, proportion of trip spent flying, and sugar content of nectar (Online Resource 2 details the Agencies approach; USEPA et al. 2012).

Numerous researchers have investigated honey bee nutrition and energetics (e.g., Haydak, 1970; Winston 1987; Herbert 1992; Brodschneider and Crailsheim 2010), and many have also estimated food ingestion rates (e.g., Haydak 1934; Brandstetter et al. 1988; Crailsheim 1998). However, these and other pertinent studies do not appear to have been included in the development of the Agencies honey bee risk assessment guidance (USEPA et al. 2012, 2014). A detailed review of relevant available data is warranted to support dietary exposure assessments, and determine if the current regulatory guidance is an appropriate, conservative, science-based benchmark.
In addition to individual dietary requirements, quantification of honey bee food consumption at the colony level including both nectar and pollen is needed. Interpretation of semi-field and field experiment results are limited by the disconnect between pesticide application rates and actual exposure. Further, colony-level exposure models would benefit from empirical data for validation.

To support the assessment of pesticide risk to honey bees at all tiers, the objectives of the current review were to compile and summarize available quantitative data on (1) provisioning and ingestion of nectar by individual nectar foragers (only, see explanation below) and (2) seasonal colony-level consumption of both nectar and pollen, for consideration in dietary exposure assessments. Herein, provisioning refers to the acts of acquiring and sharing food, whereas ingestion refers to uptake and use of food by the bee. At the individual level, we do not consider ages or castes other than foragers because the current Tier I assessment (and supporting White $\mathrm{Pa}$ per) maintains that nectar foragers have the highest potential pesticide exposure in the colony (USEPA et al. 2012, 2014). This review is focused on diet and does not include a review of xenobiotic absorption that could occur during food collection (but see Conner et al. (1978) and Davis and Shuel (1988)). Also, we are not considering here the effects of pesticides on honey bees; this includes any potential impacts on energetics or diet, though this may be an important consideration for some particular pesticides.

The data compiled for individual nectar foragers was subsequently used to model nectar requirements and compare estimates with those of the Agencies (Rodney and Kramer 2019).

Given the complex nature of honey bee food collection, storage, and ingestion, Online Resource 1 provides an overview of honey bee physiology, life cycle, behavior, energetics, social organization and supplementary feeding relevant to nutrition. The current regulatory risk assessment process for honey bees in the USA and Canada is discussed in the context of the objectives of this review in Online Resource 2. 


\section{METHODS}

A systematic review of the open literature was conducted. Web of Science, SciFinder $囚$, and Google Scholar were searched for publications related to nectar, honey, pollen, supplementation, foraging, energetics, diet, nutrition, or storage, and Apis mellifera (or honey bee or honeybee or A. mellifera). Titles and abstracts were screened for relevance, and those found to be relevant to the objectives of the review were acquired and read to determine whether the content was pertinent. Concurrently, informal consultation was carried out with experts in bee research and apiary management to acquire grey literature and information in relation to supplementation and hive management. Information was collated, and units of measure were standardized where applicable. An effort was made to distinguish between data to be considered qualitatively only, and those that could inform quantitative exposure assessment, for example, sugar feeding studies, versus natural foraging studies. Subsequently, the review was updated with more recent relevant articles based on a Web of Science search for articles from 2017 or later citing one or more of the key papers reviewed herein. The collated data are primarily presented in Online Resource 1. Synthesis of the data was not straightforward due to the diverse study objectives, inconsistency in experimental units, and statistics reported among the reviewed studies. In a subsequent modeling exercise carried out to estimate nectar forager nectar requirements (Rodney and Kramer 2019), data were integrated by calculating weighted averages and pooled variances across studies where practicable for pertinent model parameters. See Table I (Comparison of Agencies and revised model input assumptions for honey bee nectar forager nectar requirement estimates) and Table II (Summary of input assumptions for RP model for honey bee nectar forager nectar requirement estimates) in (Rodney and Kramer 2019).

\section{NECTAR FORAGING AND NECTAR REQUIREMENTS OF NECTAR FORAGERS}

All efforts were made to collate data specific to nectar foragers; however, in many cases, researchers did not distinguish between nectar foragers, pollen foragers, and/or other workers leaving the colony for other purposes (e.g., water, propolis, orientation, or defecation flights). Where a distinction was not made among foragers, we included the data for unspecified foragers as being generally applicable to nectar foragers, as nectar foragers tend to account for the majority of foragers at any given time (see Online Resource 1, and most recently Prado et al. (2019)).

\subsection{Provisioning for Nectar Foraging}

The main source of energy for foraging trips is a mixture of nectars at variable sugar concentrations (Beutler 1950; Visscher et al. 1996; Harano and Nakamura 2016). Some nectar may be acquired from in-coming foragers as part of recruitment communication, but most provisioning comes from hive bees so that the amount and sugar concentration needed can be controlled (Harano and Nakamura 2016).

The amount and the concentration of sugar taken by foragers before a trip depends on the anticipated total energy required for the round trip (Beutler 1950; Brandstetter et al. 1988; Harano and Nakamura 2016). The amount provisioned appears to be based on information from bee dances as well as olfactory and trophallactic signals that communicate the distance, identity, and quality of the food source (Beutler 1950; Harano et al. 2013; Harano and Sasaki 2015; Harano and Nakamura 2016). The volume and sugar concentration of fluid provided by the hive bees to the foragers is achieved by mixing nectar at different stages of evaporation, from freshly collected nectar to honey. Concentrations of sugar in nectar of departing bees are generally $>30 \%$. Nectar load on departure is typically far less than crop capacity (Harano and Nakamura 2016; see Online Resource 1 for relevant physiology). Specifically, for nectar foragers, Harano and Nakamura (2016) recently reported departing crop loads of approximately $2.0 \pm 2.4$ (SD) $\mu \mathrm{L} /$ bee $(n=46)$ with an average concentration of $45 \%(\mathrm{w} / \mathrm{w})$ sugar. Other values for honey bee workers but not specifically nectar foragers are provided in Table S1 (Crop loads of foraging honey bees on departure from the hive) in Online Resource 3. 


\subsection{Nectar Collection and Provisioning of the Colony}

Reports of forager activity under natural conditions were considered relevant including some with tracking devices. Foragers remain in the hive at night (Crailsheim et al. 1996; Moore et al. 1998 and references cited therein), and sleep for a portion of this time (Heusner and Stussi 1964; Kaiser 1988; Schmolz et al. 2002). Rest is not restricted to night time for foragers (Moore et al. 1989, 1998). Many workers of foraging age forage only sporadically during daylight hours. Tenczar et al. (2014) reported approximately $20 \%$ of the foraging workforce accounted for $50 \%$ of the flight activity of experimental colonies (maintained for 5-7 weeks; Illinois, USA, summer). Resting or waiting foragers provide a reserve that can become active in the event of forager losses, or to take advantage of emerging food resources (as reviewed by Anderson (2001)). Foragers can be grouped by their fidelity to particular species of flowers that are available on any given day and foraging and flight activity of groups can be limited to the time of day consistent with the availability of a particular food source (as reviewed by Moore et al. 1998). Tian et al. (2014) used radiofrequency identification (RFID) in an investigation of two colonies in China. More than half the foragers were found to take entire days off from foraging in a 38-day study period, even though conditions were favorable for foraging. Roughly one quarter of potential foraging days were not used for foraging. Foragers that did not take days off spent an equivalent amount of time foraging compared to bees that did take days off (Tian et al. 2014). The amount of time spent foraging is also a function of age. As foragers approach the end of their life, their foraging intensity generally increases (Seeley 1996; He et al. 2013; Tenczar et al. 2014).

Foraging is both risky and costly in terms of energy and resource expenditures (SteffanDewenter and Kuhn 2003). The foraging strategy at the colony level is to continuously survey the landscape around the hive and to focus foraging on preferred patches within that area (Visscher and Seeley 1982; Seeley et al. 1991). Foragers respond rapidly to changes in the environment and an empirical model of egress rates from honeybee colonies shows that $78 \%$ of the variability can be accounted for by variation in temperature and solar radiation, among weather variables considered (Clarke and Robert 2018).

When resources around the hive are adequate, and conditions are suitable for foraging, most foraging activity occurs within $1 \mathrm{~km}$ of the hive (Eckert 1933; Beekman and Ratnieks 2000; Steffan-Dewenter and Kuhn 2003; Garbuzov et al. 2015; Danner et al. 2016). The occurrence of long-range foraging may indicate a poor nutritional habitat for the bees around the hive. In Eckert's work (1933), the colonies with bees foraging for nectar further than $6.4 \mathrm{~km}$ lost weight. The frequency of foraging generally decreases exponentially with distance (Hagler et al. 2011; Garbuzov et al. 2015).

Trip duration depends not only on distance, but also on the number of flowers required to collect a load and the time per flower. Floral nectaries can contain less than a microliter to a few milliliters of nectar (Pacini and Nicolson 2007). The number of flowers visited per load can be as low as one, or might even exceed a thousand for nectar foragers depending on the plant species (Ribbands 1949; Michener 1974; van der Steen 2015). Trip duration also decreases with the number of times a forager visits a collection site due to learning (Brandstetter et al. 1988).

Recent use of tracking tools shows that the frequency and duration of foraging flights are highly variable, even among individuals of the same colony (He et al. 2013; Tenczar et al. 2014; Perry et al. 2015; Thompson et al. 2016). Reported average trip durations for foragers range from 0.19 to $2.1 \mathrm{~h}$, with a single trip reported minimum of $0.15 \mathrm{~h}$ and a maximum of $2.5 \mathrm{~h}$. See Table S2 (Summary of honey bee forager trip time data) in Online Resource 3, and also Table I (Comparison of Agencies and revised model input assumptions for honey bee nectar forager nectar requirement estimates) in Rodney and Kramer 2019). Many of these studies did not distinguish between forager type or the purposes of the trips outside the hive. Most trips outside the hive are presumed to be foraging trips. Some researchers used cutoff times to try and distinguish between foraging trips and orientation or defecation flights (Perry et al. 2015; Thompson 
et al. 2016), although more definitive methods are available (Feuerbacher et al. 2003).

The lack of distinction between pollen and nectar foragers in the more recent and comprehensive RFID studies indicates a data gap. It is unknown if there is a systematic difference in the duration of trips by bees collecting pollen, nectar, water, or propolis.

The number of trips per forager per day may in part depend on the interval between trips, also known as the turnaround time (Eckert et al. 1994). Reported mean turnaround times range from 0.23 to 0.85 h (Eckert et al. 1994; Thompson et al. 2016). The time taken to find receivers that will accept the load depends on the quality of the material brought back to the hive and the demand for nectar (Pankiw et al. 2004; Thenius et al. 2008). Longer distances will be flown for higher quality resources and during times of higher demand (van der Steen et al. 2012). Accordingly, unloading times are also linked to demand, foraging time, and distance (Schmickl and Karsai 2016).

Foraging rates at artificial feeders near the hive can be unnaturally high and are not representative of free-foraging honey bees. The frequency of visits per day by an individual bee and the duration of time spent at a food source will increase with increased sugar concentration (Fernandez and Farina 2005). With artificial controlled-flow feeders, up to 45 trips per hour were recorded with $50 \% \mathrm{w} / \mathrm{w}$ sucrose flowing continuously at $10 \mu \mathrm{L} /$ $\mathrm{min}$ and the food source $100 \mathrm{~m}$ from the hive. With a flow rate of $2-5 \mu \mathrm{L} / \mathrm{min}$, the number of trips per hour ranged from 4 to 16 , with fewer trips per hour to a site $2000 \mathrm{~m}$ from the hive (Núñez and Giurfa 1996). An extreme value of 150 trips per bee per day was cited in Winston's review (Winston 1987) of Ribbands (1953). This value was found to be associated with an artificial feeder and represents total trips taken by two bees (Butler et al. 1943).

Under natural foraging conditions, mean numbers of trips per day by workers range from 1 to 13.5, with a maximum reported value of 24 trips for a single bee-day. See Table S3 (Summary of data collected on number of trips taken per day by honey bee workers) in Online Resource 3, and also Table I (Comparison of Agencies and revised model input assumptions for honey bee nectar forager nectar requirement estimates) in Rodney and Kramer (2019). Again though, the purposes of the trips were generally not reported but are presumed to be primarily foraging trips.

Overall average time outside the hive per flying day falls between 0.95 and $3.06 \mathrm{~h}$. See Table S4 (Summary of RFID results reporting on mean time spent outside the hive by honey bee workers) in Online Resource 3, and also Table II (Summary of input assumptions for RP model for honey bee nectar forager nectar requirement estimates) in Rodney and Kramer (2019). In addition, Thom et al. (2000) reported that $70 \%$ of nectar foragers in their study foraged for less than $4.5 \mathrm{~h}$ (despite over $15 \mathrm{~h}$ of daylight). He et al. (2013) reported a maximum of $6.25 \mathrm{~h}$ from their study. The average time outside the hive, by age, increased from 0 to approximately $2.9 \mathrm{~h}$ (See Online Resource 1 for more background on this). Alaux et al. (2014) reported average time outside the hive per day for foragers over a 35-day study period in France (these data included non-flying days; and examined effects of Nosema and immune system challenge). For early/initial untreated (control, $n=103$ ) foragers, the mean time outside the hive was 1.41 $\mathrm{h} /$ day, from day 13 to the end of the study, the mean increased to $4.72 \mathrm{~h}$ /day for untreated controls. These results are also in line with those presented earlier this year by Prado et al. (2019; see Figure 3 therein). Unfortunately, in most of these investigations, the food resources were not well characterized.

Nectar foragers do not always fill their crops on foraging trips due to the metabolic cost of transport, and a possible drive to maximize energetic efficiency (see Schmid-Hempel et al. 1985; Schmid-Hempel 1987; Núñez and Giurfa 1996; Stabentheiner and Kovac 2016). The amount of sugar solution collected per trip (crop load) increases in volume with increasing flow rate, temperature, sugar concentration, and distance from the hive (Núñez 1970; Núñez and Giurfa 1996; Nicolson et al. 2013). Also, different races of honey bees will carry significantly different quantities of nectar back to the hive (Worswick 1988). Based on direct measurement of nectar, sucrose solutions provided artificially, and estimates of solution removed from feeders, the reported crop loads in foraging bees on return to the hive ranged from about 6 to $60 \mu \mathrm{L} /$ bee. See Table S5 (Crop 
loads of nectar foraging honey bees on return to the hive) and Table S6 (Sugar solution crop loads of forager honey bees on return to the hive) in Online Resource 3. When considering the smaller dataset of natural nectar crop loads only, means fall between 6 and $33 \mu \mathrm{L} /$ bee (Soehngen and Jay 1974; Worswick 1988; Calderone and Page 1992; Eckert et al. 1994; Huang and Seeley 2003; Table S5 in Online Resource 3). In a study by Huang and Seeley (2003), crop loads under natural foraging conditions did not exceed $48 \mu \mathrm{L} /$ bee.

\subsection{Nectar and Honey Requirements of Nectar Foragers}

Estimates of nectar ingestion requirements by bees have been derived using two general approaches: (1) the more direct measurements of dietary intake, including methods employing mass differences and tracers (e.g., Nachtigall et al. 1989; Balderrama et al. 1992; Gmeinbauer and Crailsheim 1993; Tomlinson et al. 2017) and (2) studies of energetics, including both calorimetric and respirometric measures of heat production and gas exchange, respectively (Coelho and Mitton 1988; Nachtigall et al. 1989; Wolf et al. 1989; Balderrama et al. 1992; Stabentheiner et al. 2003a, b; Moffatt and Núñez 1997; Stabentheiner and Kovac 2016). The latter is more prevalent in the literature. Each gram of sugar equates to approximately $17 \mathrm{~kJ}$ (or 4 kilocalories). At standard temperature and pressure, oxygen use or $\mathrm{CO}_{2}$ production of a bee can be converted to $\mathrm{kJ}$ using the standard conversion of $21.17 \mathrm{~kJ} / \mathrm{L}$ (Hartfelder et al. 2013). Generally, the lowest demand for sugar occurs in foragers at ectothermic rest, and the highest demand occurs when bees are hovering or flying. See Table S7 (Estimates of sugar metabolism by resting or motionless honey bee workers), Table S8 (Estimated sugar metabolism of tethered flying honey bee workers) and Table S9 (Estimates of sugar metabolism by honey bee workers performing a variety of activities (untethered)) in Online Resource 3, and also Table I (Comparison of Agencies and revised model input assumptions for honey bee nectar forager nectar requirement estimates) in Rodney and Kramer (2019). However, there are a number of factors other than observed activity level that impact metabolism in individual workers. These factors include age (Fahrenholz et al. 1989, 1992), body mass (Wolf et al. 1989); ambient air temperature (Allen 1959; Cahill and Lustick 1976; Schmolz et al. 2002; Stabentheiner and Kovac 2016), degree of solar radiation (Stabentheiner and Kovac 2016), air pressure (Withers 1981), degree of agitation (Woods et al. 2005), characteristics of the food source (Moffatt 2000), and other behaviors such as foraging in clusters or isolation (Free and Spencer-Booth 1958; Heusner and Stussi 1964; Fahrenholz et al. 1989). These factors can also interact, complicating accurate prediction of individual metabolism (see for example Schmolz et al. 2002; Woods et al. 2005; Stabentheiner and Kovac 2016).

Reports of energy consumption in a resting state should be interpreted with caution as bees are easily roused to a sustained endothermic state of higher energy use even when they appear to be at rest (Hartfelder et al. 2013). Table S7 in Online Resource 3 (Estimates of sugar metabolism by resting or motionless honey bee workers) summarizes data for workers in isolation or groups (Cahill and Lustik 1976). In general, mean estimates from these studies tend to be $<1 \mathrm{mg}$ sugar per hour. The results of Allen (1959), Heusner and Stussi (1964), Stabentheiner et al. (2003b), and Kovac et al. (2014) apply specifically to foragingage workers, but none of the data are attributed to nectar foragers exclusively. In general, metabolism of bees observed at rest appears to be correlated with ambient air temperature, though the nature of the relationship differs among studies. Cahill and Lustik (1976) report a linear decline in metabolism of "resting" workers with increased air temperature from 5 to $40{ }^{\circ} \mathrm{C}$. By contrast, Heusner and Stussi (1964) and Schmolz et al. (2002) report an increase in metabolism of "sleeping" bees with increased ambient air temperature between 15 and $35^{\circ} \mathrm{C}$. This discrepancy may be due to differences between states of sleep and wakeful resting. As proposed by Schmolz et al. (2002), sleeping bees at optimal sleep temperature (of $\sim 28{ }^{\circ} \mathrm{C}$ ) increase their metabolic rate for restorative processes. Tomlinson et al. (2015) also reported an increase in metabolism of workers held motionless with increased temperature in the range of 15 to $30{ }^{\circ} \mathrm{C}+$, with a sharp decline at 32 and $42{ }^{\circ} \mathrm{C}$ in early and late season 
foragers, respectively. In this case, the test was one hour long with bees captured within the hour prior to testing. There was no report of the bees being fed, leading to the question of whether or not the bees were dealing with depleted energy reserves. Both Allen (1959) and Stabentheiner et al. (2003a) report non-monotonic responses to increased temperature, but in agreement with Cahill and Lustik (1976), these authors reported a general decline in metabolism of relatively motionless bees with increasing ambient air temperature in the range of 15 to $25^{\circ} \mathrm{C}$, with the former reporting further declines to $32{ }^{\circ} \mathrm{C}$. Reported average resting metabolism estimates at ambient air temperatures between 20 and $25^{\circ} \mathrm{C}$ (typical of the temperate growing seasons) ranged from $0.0750 \mathrm{mg}$ sugar/hr (bees "sleeping" at $20{ }^{\circ} \mathrm{C}$; Schmolz et al. 2002) to $2.83 \mathrm{mg}$ sugar/h (workers "resting" at $25{ }^{\circ} \mathrm{C}$; Cahill and Lustik 1976.

As noted in Table S7 in Online Resource 3, the "resting" metabolism data were from bees predominantly in isolation from other bees. Bees in clusters are able to reduce their metabolism relative to isolated bees (see Fahrenholz et al. 1989, 1992). Fahrenholz et al. (1989) demonstrated an apparent exponential decline in weight-specific heat production in worker groups of one to 18 individuals at an ambient $30{ }^{\circ} \mathrm{C}$ in a $100-\mathrm{mL}$ vessel. These results suggest that resting metabolism in the hive may be considerably lower than that observed in studies with isolated individuals, suggesting an energetic advantage to hive living adopted by honeybees.

Metabolism generally increases with activity level. Tables S8 and S9 in Online Resource 3 present metabolism estimates for bees engaging in different activities from sitting and walking, to hovering and flying. Two studies reviewed involved tethered flights carried out in the laboratory (Table S8 in Online Resource 3). In these types of experiments, bees are generally strung by the thorax and prompted to fly in circles. As reviewed by Nachtigall et al. (1989), tethered flight generally requires less energy than free flying. This is probably due to the relatively low vertical force required to compensate for body weight. Also, generally lower flight speeds are achieved in tethered energetics experiments.

Several studies have examined the effects of ambient air temperature on the metabolism of active (untethered) honey bees. Isolated bees at a lower level activity (e.g., sitting with some movement, walking around) were found to have decreasing metabolism with increasing temperature in the range of 15 to $35^{\circ} \mathrm{C}$ (Heusner and Stussi 1964; Blatt and Roces 2001; Stabentheiner et al. 2003b). At $25{ }^{\circ} \mathrm{C}$, Stabentheiner et al. (2003b) reported mean metabolism for these types of activities in the range of 3 to $7 \mathrm{mg}$ sugar/bee/h, which is consistent with the findings of others (see Table S9 in Online Resource 3). Foraging, and flight in particular, requires considerably more energy. For bees in flight, Roberts and Harrison (1999) and Woods et al. (2005) reported a negative relationship between metabolism and ambient air temperature in the range of 21 to $38{ }^{\circ} \mathrm{C}$. However, the latter authors found that when the bees were not agitated to fly (e.g., tapping or shaking of the vessel), the negative relationship did not hold. When bees were predominantly in flight, metabolism was relatively consistent for tested bees between 15 and $40{ }^{\circ} \mathrm{C}$. Between 20 and $25^{\circ} \mathrm{C}$, average reported metabolism for bees in flight or hovering fell between 9 and $14 \mathrm{mg}$ sugar/bee/h (see Table S9 in Online Supplement 3). When foraging in relatively large vessels (6-7 L), with flight between artificial feeders, workers have exhibited decreased metabolism with increased ambient air temperature between 19 and $30{ }^{\circ} \mathrm{C}$ (Moffatt 2001). Under these conditions, between 20 and $25^{\circ} \mathrm{C}$, average metabolism estimates tend to fall between 5 and $10 \mathrm{mg}$ sugar/bee/h.

In smaller measurement vessels $(\sim 8 \mathrm{~mL})$ used outdoors over short sampling periods (generally less than $5 \mathrm{~min}$ ) with single artificial feeders, Stabentheiner et al. (2012) and Stabentheiner and Kovac $(2014,2016)$ demonstrated increased metabolism with increased flow rate of sugar solution. In general, solar radiation appears to lead to decreased metabolism, except when flow rates are high (e.g., Stabentheiner and Kovac 2016) and ambient temperature is relatively low $\left(15-23^{\circ} \mathrm{C}\right)$. This effect has been attributed to acquiring resources when conditions are optimal (Stabentheiner and Kovac 2014, 2016). Under the conditions of these studies, metabolism was observed to be more variable, but generally falling in the range of other studies 
reporting on energetics of foraging and flight (see Table S9 in Online Resource 3).

In a recent and novel study, average field metabolic rate and nectar consumption was estimated for free flying honey bees over 6 days using flowthrough respirometry and radiolabeled isotopes of ${ }^{86} \mathrm{Rb}$ and ${ }^{22} \mathrm{Na}$, respectively (Tomlinson et al. 2017). The study compared results for bees from hives ( 3 per location) located in a natural woodland where Banksia spp. were prevalent for nectar foraging, and a deforested plantation. Only 13 of an original 70 bees enriched with radiolabeled material were recaptured (it was not clear how many bees were retrieved from each location). Bees from the forested area produced an estimated $9.91 \pm 0.94(\mathrm{SE}) \mathrm{mL} \mathrm{CO}_{2}$ per day and consumed $164.6 \pm 31.0$ (SE) $\mu \mathrm{L}$ nectar per day. Bees from the deforested area produced an estimated $6.82 \pm$ 1.08 (SE) $\mathrm{mL} \mathrm{CO}_{2}$ per day and consumed $65.9 \pm$ 27.4 (SE) $\mu \mathrm{L}$ nectar per day. The authors reported that the mean nectar consumption estimates were 202 and $67 \mathrm{mg}$ nectar per day for woodland and deforested areas, respectively. The authors did not report their methods of estimating nectar mass. Banksia spp. nectar concentrations are variable but are likely to fall between $\sim 5$ and $45 \%$ (w/w) sugar based on samples from three species (Davis et al. 2015). Unfortunately, in addition to the lack of sugar concentration in nectar, the sample sizes were very small and bee ages were not reported. The $\mathrm{CO}_{2}$ production can be converted directly into grams per day of sucrose. At standard temperature and pressure (STP), we can assume approximately $21.1 \mathrm{~J} / \mathrm{mL} \mathrm{CO}$ and $16.8 \mathrm{~J} / \mathrm{mg}$ sucrose (Hartfelder et al. 2013). In this case, mean estimates of $\mathrm{CO}_{2}$ per day would convert to $0.519 \mathrm{mg} \mathrm{sugar} / \mathrm{h}$ and $0.357 \mathrm{mg} \mathrm{sugar} / \mathrm{h}$, for the forested and unforested areas, respectively (e.g., $9.91 \mathrm{~mL} /$ day of $\mathrm{CO}_{2} \times 21.1 \mathrm{~J} / \mathrm{mL} \mathrm{CO}_{2}=209.1$ $\mathrm{J} /$ day, $209.1 \mathrm{~J} /$ day $\div 16.8 \mathrm{~J} / \mathrm{mg}$ sugar $=12.45 \mathrm{mg}$ sugar per day, $12.45 \mathrm{mg}$ sugar/day $\div 24 \mathrm{~h} /$ day $=$ $0.519 \mathrm{mg} \operatorname{sugar} / \mathrm{h})$. The equivalent amounts of $30 \%(\mathrm{w} / \mathrm{w})$ sugar content of nectar would be approximately 41.5 and $28.6 \mathrm{mg}$ nectar/bee/day (e.g., $12.45 \mathrm{mg} \mathrm{sugar} /$ day $\div 0.30=41.5 \mathrm{mg}$ nectar$/$ day). With some refinement, the method presented by Tomlinson et al. (2017) may be used to better characterize nectar consumption by nectar foragers.

\section{SEASONAL FOOD COLLECTION, STORAGE, AND CONSUMPTION BY COLONIES}

Below, we provide a summary of information found regarding the quantities of pollen and nectar acquired, kept and used by honey bee colonies. In addition to natural food resources, managed colonies are frequently supplemented with other sources of sugar and protein. Such supplementation is highly variable among apiculturists, and we found supplementation information to be currently insubstantial. Our collated information on this subject is detailed in Online Resource 4.

\subsection{Collection, Storage, and Consumption of Nectar by Colonies}

Many reports of annual nectar collection by colonies are anecdotal. Seeley (1996) and van der Steen (2015) reported average values of $120-125 \mathrm{~kg}$ of nectar collected per year per colony, but source and sugar content were omitted. Other annual nectar collection estimates for colonies have been based on honey production (136$259 \mathrm{~kg}$; Southwick and Pimentel 1981; Flottum 2014). The flaw with the latter approach is that the honey in a hive at the end of a season, or any fixed point in time, only accounts for nectar not digested. Seeley (1996) estimated that about $70 \mathrm{~kg}$ of nectar would be required for a colony to rear brood and fuel foraging over the summer.

Factors affecting colony level nectar collection include but are not limited to: population size and demographics of the colony, environmental conditions, and available nectar resources within the foraging range and their locations relative to the hive. If the colony must produce wax for comb building, additional nectar collection is required because wax is synthesized directly from sugar by wax glands. The production of $1 \mathrm{~kg}$ of wax requires $8.4 \mathrm{~kg}$ of honey (Black 2006), or approximately $23 \mathrm{~kg}$ of nectar (assuming honey and nectar are $82 \%$ and $30 \%$ sugar, respectively), and will produce 77,000 comb cells (Dadant 1992).

Based on gravimetric analyses in temperate locations, nectar is only sufficiently abundant for hives to increase in mass for approximately 10 weeks of the year, distributed over the spring and 
summer. During the remainder of the growing season, nectar flows were either just enough to maintain hive mass, or insufficient with the hive losing some mass, particularly in mid to late summer (e.g., Soehngen and Jay 1973; Seeley 1996).

The collection of large surpluses of nectar requires a major investment of energy and space in the hive devoted to processing and storage in waxcapped cells. The investment ensures that nectar is available during times of dearth in the summer and for overwintering in temperate regions or during the dry season in tropical regions (Seeley and Visscher 1985). Seeley (1996) suggested that $50 \mathrm{~kg}$ of collected nectar is typically stored as honey for the flowerless months in a temperate climate, equivalent to $\sim 18 \mathrm{~kg}$ of honey, assuming nectar is $30 \%$ sugar, and honey is about $82 \%$ sugar). Using data collected in 2015 from multiple states and operations with five or more colonies, the US Department of Agriculture reported that, on average, managed colonies produce $29.5 \mathrm{~kg}$ of honey harvested per year (USDA 2016). However, there is considerable variability in average colony yields across individual reporting states $(n=40)$, i.e., ranging from an average of 12.2 to $46.3 \mathrm{~kg}$ honey/colony from New Jersey to Hawaii, respectively. Despite the paucity of nectar collection data at the colony level, there is clearly a high degree of variability in annual nectar collection by colonies across the USA, assuming honey stores are indicative of nectar collection effort. Beekeepers will often leave some honey in the hive for overwintering although the amounts have not been well documented. For overwintering, 18-27 $\mathrm{kg}$ and $7-14 \mathrm{~kg}$ of honey are recommended as reserves in temperate and southern regions, respectively (Furgala and McCutcheon 1992).

We were unable to find any studies directly measuring colony-level consumption of nectar over a year. The available information on nectar (or honey) required per year could be estimated from the amount of stored food required to sustain a colony, e.g., $4.5 \mathrm{~kg}$ /hive per week in spring (Ambrose 1992). Herbert (1992) reported a summer honey requirement of $43 \mathrm{~kg}$. However, these needs would vary with colony size and demographics. During winter, there is no incoming nectar in temperate regions. Bees remain in the hive when average air temperatures drop below 7
$-16{ }^{\circ} \mathrm{C}$ (Abou-Shaara 2014). In northern temperate regions, the consumption of $19-25 \mathrm{~kg}$ of honey has been reported from the end of brood rearing until spring nectar flows. The presence of brood after mid-February increased the consumption rate from 0.37 to $3.9 \mathrm{~kg} /$ week (Furgala and McCutcheon 1992, and references cited therein). Roughly, thirteen spring weeks at $4.5 \mathrm{~kg}$ honey per week $=58.5 \mathrm{~kg}, 58.5 \mathrm{~kg}$ (spring) $+43 \mathrm{~kg}$ (summer) + 19-25 kg (end of brood rearing to spring nectar flow) $=120.5$ to $126.5 \mathrm{~kg} /$ year $/$ colony of honey. Assuming collected nectar is $30 \%$ sugar and stored honey is $82 \%$ sugar, this equates to between 329 and $346 \mathrm{~kg}$ of nectar per colony per year. Lower nectar sugar concentration assumptions would yield higher estimate, as would higher honey sugar concentrations, and again the estimates are strong influence by the characteristics of the colonies that generated the inputs, a great deal of variability is expected.

\subsection{Collection, Storage, and Consumption of Pollen by Colonies}

Pollen consumption is considered significant for risk assessment of honey bees at life stages prior to foraging, particularly nurse bees (Online Resource 1; USEPA et al. 2012, 2014). According to Winston (1987) and Seeley (1996), annual pollen collection ranges from $20-30 \mathrm{~kg} /$ colony, though no sources or supporting data were provided. One of the most common methods to quantify the amount of pollen collected by colonies is pollen trapping. A pollen trap is a screened device installed across the entrance to the hive. The grid size of the screen must be large enough that foragers can get through, but small enough that some pollen loads will be scraped from the corbicula of entering bees (Delaplane et al. 2013). Reported trapping efficiencies vary considerably in the literature, with averages ranging from 10 to $60 \%$ (Rashad and Parker 1958; McLellan, 1976; O'Neal and Waller 1984; Dimou and Thrasyvoulou 2007; Forcone et al. 2011; Odoux et al. 2012; Avni et al. 2014). Trapping efficiency is generally reported as the number of pollen loads trapped as a fraction of the total loads brought back to the hive, with a maximum of two pollen pellets removed per returning bee. However, to 
get an accurate estimate of the mass of pollen being collected, it is desirable to determine trap efficiency on a mass basis (Rashad and Parker 1958). Unfortunately, in many cases, mass-based trapping efficiency is not reported (Eckert 1942; Herbert et al. 1985; Garcia-Garcia et al. 2001; Dimou et al. 2006; Wilde et al. 2011; Kumar and Agrawal 2014), or its application to the results is not clear (Dimou and Thrasyvoulou 2007; Requirer et al. 2015). In these studies, total mass of pollen collected by bees could not be estimated or confirmed.

As demonstrated by Rashad and Parker (1958), pollen trapping has a significant impact on pollen collection efforts made by the colony, and also on brood rearing. Colonies subjected to trapping $(53 \%(\mathrm{w} / \mathrm{w})$ efficiency) in their study increased pollen collection by $81.5 \%$. Despite this increase in foraging effort, brood rearing was reduced by $15.25 \%$, on average. Accordingly, pollen trapping may not provide a good indication of pollen collection under typical conditions. Rashad and Parker (1958), Forcone et al. (2011), and Avni et al. (2014) reported trapping efficiencies and accounted for them in their estimates of pollen collection. Annual estimates ranged from 8.4 to $29 \mathrm{~kg}$ pollen/colony. See Table S10 (Pollen trapping and estimated collection by free flying honey bee foragers) in Online Resource 3. Some of these estimates, however, were likely influenced by high trapping efficiency leading to concurrent increases in pollen foraging efforts.

Under flight cage conditions $(3 \times 3 \times 2 \mathrm{~m})$, Campana and Moeller (1977) offered various pollens (obtained by trapping and offered in patty form) to colonies of equivalent size ( 4 colonies per cage, 6 cages each with a different type of pollen offering). Colonies were of mixed age and each had $\sim 7,000$ bees $(\sim 0.91 \mathrm{~kg}$ of bees $)$ at the start of the study. The hives had no food at the start of the test, but colonies were offered water, $67 \%$ sugar syrup and the selected pollen preparations for the cage (i.e., blackberry, willow, sweet clover, boxelder, fruit bloom, or a mix of pollens). Collection of the pollen under these artificial conditions was recorded over 45 days, along with brood rearing. Average collection over the 45 days ranged from 8.45 to $15.2 \mathrm{~g} /$ colony/day, with clover pollen preferred (Campana and Moeller
1977). A similar experimental design was employed by Herbert and Shimanuki (1982), who investigated use of lactalbumin/yeast as a pollen substitute at different colony sizes. The authors used fresh and aged pollen as controls and reported that $400 \mathrm{~g}$ bee colonies $(\sim 4000$ bees/colony, $n=4$ per treatment) offered $50 \mathrm{~g}$ of pollen per week collected 32.2 and $43.3 \mathrm{~g} /$ week on average over 12 weeks of 1 -year old pollen and fresh pollen respectively (or 4.60 and $6.19 \mathrm{~g} /$ day). Herbert et al. (1988) also investigated protein substitutes over a 12-week study and compared results with collection of trap pollen. Trap pollen was from four nuclei of $\sim 4000$ bees (400 g) per diet ( 2 colonies per cage) at reported average rates of between 91 and $145.8 \mathrm{~g} / 2$-week period (6.5 to $10.4 \mathrm{~g} /$ colony/day).

These pollen collection values are considerably lower than those reported by Rashad and Parker (1958) when accounting for starting colony size. The discrepancy may be explained in part by the unnatural flight cage conditions, differences in demographics, and initial hive resources. Further, pollen trapping by Rashad and Parker (1958) dramatically increased pollen collection (81.5\% increase). Results of the flight cage studies are more in line with the results of Avni et al. (2014), and this may be in part because pollen trapping in this study was only intermittent (Table S10 in Online Resource 3). Unfortunately, most authors did not report on the size or demographics of the colonies from which pollen collection was measured. This limits the use of these data with respect to forecasting collection levels. Further, collection by any one colony is expected to vary temporally over the course of a year (Rashad and Parker 1958; Forcone et al. 2011; Ismail et al. 2013; Requirer et al. 2015).

Despite upwards of $30 \mathrm{~kg}$ potentially being collected by a colony through a year, much less is stored. Pollen cells are on average only slightly more than half full and contain on average between 143 and $183 \mathrm{mg}$ of packed pollen (Rashad and Parker 1958, and references cited therein).

Jeffree and Allen (1957) measured pollen stores regularly in 25 colonies over 8 years in Aberdeen, Scotland (peak size of $\sim 24,000$ bees). 
On average, pollen stores in winter were low and stable at $\sim 74-94 \mathrm{~g} /$ colony because there is little or no brood rearing. This range was estimated from the area of pollen cells assuming 4 cells per $\mathrm{cm}^{2}$ (Delaplane et al. 2013) and 143-183 mg/cell. In summer, stores markedly increased to a single peak in July that was nearly nine times greater than winter pollen storage. Based on regression of a measure of pollen area versus colony size, Jeffree and Allen (1957) estimated that peak storage in July for a larger colony of 40,000 bees was approximately $1.2 \mathrm{~kg}$.

We were unable to find any studies of pollen consumption based on measured collection minus storage in the open literature. The most direct measurement of pollen consumption by honey bees available is based on dissection and counting pollen grains in the alimentary canal of individual worker bees from two colonies of Apis mellifera carnica kept outdoors in summer in Austria (Crailsheim et al. 1992). See Table S11 (Pollen ingestion by adult worker honey bees from Crailsheim et al. (1992)) in Online Resource 3.

The total amount of pollen estimated per colony was 13.4 and $17.8 \mathrm{~kg} /$ colony/year for the two colonies, which falls within the range of annual collection estimates from the literature (8.4 to $29 \mathrm{~kg}$ pollen/colony/year, see Table S10 in Online Resource 3). The overall average of $3.9 \mathrm{mg}$ pollen/bee from Crailsheim et al. (1992) is consistent with an earlier, less detailed report by Schmidt and Buchmann (1985) who reported 3.4 $\mathrm{mg} /$ bee/day over 28 days.

\section{DISCUSSION}

With respect to nectar foragers, we conclude that there are substantial data describing crop loadings before and after foraging trips. There is also ample information regarding energy requirements and sugar consumption under a variety of activity levels, loadings and air temperatures. Major data gaps include quantification of correlations between foraging trip variables (e.g., time per trip and number of trips), and the fraction of time spent at various levels of energy expenditure. The dietary exposure assessment for honey bee nectar foragers would benefit from additional confirmatory research on:
(1) Time spent outside the hive by nectar foragers in representative agroecosystems.

(2) Proportions of time spent at various levels of energy expenditure under natural conditions (e.g., flying, hovering, resting, and endothermal versus ectothermal states).

(3) The distribution of sugar concentrations of nectars collected by nectar foragers, giving special consideration to crop nectar (see Knopper et al. 2016).

(4) For more refined assessments that account for the fate and behavior of the pesticide, it would be useful to determine the relative amounts of fresh nectar, aged honey, and water ingested.

Recent advances in tracking (e.g., RFID) of honeybees could prove useful to collect some of the above information (see Capaldi et al. 2000; Riley et al. 2005; Decourtye et al. 2011; He et al. 2013; Tenczar et al. 2014; Perry et al. 2015; Liao et al. 2017; and particularly, Thompson et al. 2016). Further the tracer techniques of Tomlinson et al. (2017) could also be effective in deriving more precise estimates of energy requirements of foragers.

Given recent data collected with radio frequency identification tracking techniques, and the supporting review of forager behavior, we contend that nectar foragers likely spend considerably less time foraging than what has been calculated by the Agencies (median of 8.9 hours per day; USEPA, PMRA and CDPR 2012). The Agencies median of $292 \mathrm{mg} / \mathrm{nectar} / \mathrm{bee} /$ day for nectar foragers (USEPA, PMRA and CDPR 2012, 2014) is unrealistically high for nectar foragers on the whole. A revised median estimate of $44 \mathrm{mg}$ nectar/bee/day was calculated in a modeling effort based on the data reviewed herein (Rodney and Kramer 2019). Filling identified data gaps should lead to more refined screening and probabilistic estimates of nectar and honey ingestion by foragers.

With respect to colony-level nectar collection, consumption, and storage, we conclude that there is a paucity of data, and insufficient information for refining exposure estimates. There are considerable concerns regarding the quality of the data available with respect to use in exposure assessment. Particularly, we lack the information to 
quantify expected relationships between environmental conditions, colony demographics and nectar flow through the colony. Similarly, with respect to colony-level pollen collection, consumption and storage, there is a lack of data that could be used to accurately predict influx and uptake by colonies under natural foraging conditions. These concerns also extend to supplemental feeding which, in some scenarios, may be regimented in terms of offerings, but removal of unconsumed material has not been measured and the effects of deterioration prior to consumption has not been considered. We recommend field-level investigation of colony-level consumption over time in representative hives via inference from rolling assessments (different set of hives at each sampling point, with low frequencies on individual hives to minimize colony disruption) of consumption and storage, along with electronic hive monitoring (Human et al. 2013).

\section{ACKNOWLEDGMENTS}

We would like to thank staff of Intrinsik Corp. for their assistance in compiling, grouping, and documenting the literature reviewed herein. We would also like to express gratitude to Vincent Kramer, Chris Cutler, Rick Fell, Cynthia Scott-Dupree, Dwayne Moore, and Scott Teed for their comprehensive review of earlier drafts of this manuscript.

\section{AUTHORS CONTRIBUTION}

Both authors have contributed equally to the work.

\section{FUNDING INFORMATION}

This work was funded by the Pollinator Research Task Force, a limited liability corporation comprised of manufacturers of crop protection products, created for the purpose of generating scientific data for the improvement of pollinator risk assessment.

\section{COMPLIANCE WITH ETHICAL STANDARDS}

Conflict of interest The authors declare that they have no conflict of interest.

\section{OPEN ACCESS}

This article is distributed under the terms of the Creative Commons Attribution 4.0 International License (http://creativecommons.org/licenses/by/4.0/), which permits unrestricted use, distribution, and reproduction in any medium, provided you give appropriate credit to the original author(s) and the source, provide a link to the Creative Commons license, and indicate if changes were made.

Exigences alimentaires à l'échelle de l'individu et consommation de pollen et de nectar à l'échelle de la colonie: une synthèse pour soutenir l'évaluation de l'exposition aux pesticides des abeilles.

Apis mellifera / abeille mellifère / diète / alimentation / besoin énergétique / butineuse.

Nahrungsanforderungen individueller Nektarsammlerinnen und Pollen- und Nektarverbrauch des Volkes: Eine Übersicht zur Unterstützung der Beurteilung der Pestizidexposition von Honigbienen.

Apis mellifera / Honigbiene/ Nahrung / Ernährung / Energetik / Sammlerin.

\section{REFERENCES}

Abou-Shaara, H.F. (2014) The foraging behaviour of honey bees, Apis mellifera: A review. Veterinarni Medicina. 59(1), $1-10$

Alaux, C., Crauser, D., Pioz, M., Saulnier, C., Le Conte, Y. (2014) Parasitic and immune modulation of flight activity in honey bees tracked with optical counters. The Journal of Experimental Biology 217, 3416-3424

Allen, M.D. (1959) Respiration rates of worker honeybees of different ages and at different temperatures. J. Exp. B. 36, 92-101

Ambrose, J.T. (1992) Management for Honey Production. In: The Hive and the Honeybee, Revised edition, Graham, J. M., Ed. Dadant \& Sons: Hamilton, IL. 1992, 601-656

Anderson, C. (2001) The adaptive value of inactive foragers and the scout-recruit system in honey bee (Apis mellifera) colonies. Behav. Ecol. 12(1), 111-119

Avni, D., Harmen, P., Hendriksma, P., Dag, A., Unic, Z., Shafira, S. (2014) Nutritional aspects of honey beecollected pollen and constraints on colony 
development in the eastern Mediterranean. J. Insect. Physiol. 69, 65-73

Balderrama, N.M., Almeida, L.O., Núñez, J.A. (1992) Metabolic rate during foraging in the honeybee. J. Comp. Physiol. B. 162, 440-447

Beekman, M., Ratnieks, F.L.W. (2000) Long-range foraging by the honey-bee, Apis mellifera L. Funct. Ecol. 14(4), 490-496

Beutler, R. (1950) Zeit und Raum im Leben der Sammelbiene. Die Naturwissenschaften. 37, 102-106

Black, J. (2006) Honeybee Nutrition: Review of research and practices. Barton, Australia, A report for the Rural Industries Research and Development Corporation, 79

Blatt, J., Roces, F. (2001) Haemolymph sugar levels in foraging honeybees (Apis mellifera carnica): Dependence on metabolic rate and in vivo measurement of maximal rates of trehalose synthesis. Journal of Experimental Biology. 204(15), 2709-2716

Brandstetter, M., Crailsheim, K., Heran, H. (1988) Provisioning of food in the honeybee before foraging. In BIONA-report 6, Akad. Wiss u Lit W Nachtigall. Mainz, Stuttgart, G. Fischer, 129-148

Brodschneider, R., Crailsheim, K. (2010) Nutrition and health in honey bees. Apidologie 41, 278-294

Butler, C.G., Jeffree, E.P., Kalmus, H. (1943) The behaviour of a population of honeybees on an artificial and on a natural crop. J. Exp. Bio. 20, 65-73

Cahill, K., Lustik, S. (1976) Oxygen consumption and thermoregulation in Apis mellifera workers and drones. Comp. Biochem. Physiol. 55A, 355-357

Calderone, N.W., Page Jr., R.E. (1992) Effects of interactions among genotypically diverse nestmates on task specialization by foraging honey bees (Apis mellifera). Behav. Ecol. Sociobiol. 30, 219-226

Campana, B.J., Moeller, F.E. (1977) Honey bees: preference for and nutritive value of pollen from five plant sources. J. Econ. Entomol. 70, 39-41

Capaldi, E.A., Smith, A.D., Osborne, J.L., Fahrbach, S.E., Farris, S.M., et al. (2000) Ontogeny of orientation flight in the honeybee revealed by harmonic radar. Nature 403, 537-540

Clarke, D., Robert, D. (2018) Predictive modelling of honey bee foraging activity using local weather conditions. Apidologie 49, 386-396

Coelho, J.R., Mitton, J.B. (1988) Oxygen consumption during hovering is associated with genetic variation of enzymes in honey bees. Funct. Ecol. 2(2), 141-146

Conner, W.E., Wilkinson, C.F., Morse, R.A. (1978) Penetration of insecticides through the foregut of the honeybee (Apis mellifera L.). Pestic. Biochem. Phys. 9, 131-139

Crailsheim, K., Schneider, L.H.W., Hrassnigg, N., Bühlmann, G., Brosch, U., et al. (1992) Pollen consumption and utilization in worker honeybees (Apis mellifera carnica): dependence on individual age and function. J. Insect. Physiol. 38(6), 409-419
Crailsheim, K., Hrassnigg, N., Gmeinbauer, R., Szolderits, M.J., Schneider, L.H.W., Broscht, U. (1993) Pollen utilization in non-breeding honeybees in winter. J. Insect. Physiol. 39(5), 369-373

Crailsheim, K., Hrassnigg, N., Stabentheiner, A. (1996) Diurnal behavioural differences in forager and nurse honey bees (Apis mellifera carnica Pollm). Apidologie. 27, 235-244

Dadant, C.C. (1992) Beekeeping Equipment. In: The Hive and the Honeybee, Revised edition. J. M. Graham, ed. Dadant \& Sons, Hamilton, IL

Danner, N., Molitor, A.M., Schiele, S., Haertel, S., SteffanDewenter, I. (2016) Season and landscape composition affect pollen foraging distances and habitat use of honey bees. Ecol. Appl. 26(6), 1920-1929

Davis, A., Major, R.E., Taylor, C.E. (2015) The association between nectar availability and nectarivore density in urban and natural environments. Urban Ecosyst. 18, 503-515

Davis, A.R., Shuel, R.W. (1988) Distribution of C-14labeled Carbofuran and Dimethoate in royal jelly, queen larvae and nurse honeybees. Apidologie. 19, $37-50$

Decourtye, A., Deviller, J., Aupinel, P., Brun, F., Bagnis, C., et al. (2011) Honeybee tracking with microchips: a new methodology to measure the effects of pesticides. Ecotox. 20, 429-437

Delaplane, K.S., Van Der Steen, J., Guzman, E. (2013) Standard methods for estimating strength parameters of Apis mellifera colonies. In V. Dietemann; J.D. Ellis, P. Neumann (Eds) The Coloss Beebook, Volume I: standard methods for Apis mellifera research. J. Apicul. Res. 52(1), 1-12. https://doi.org/10.3896/IBRA.1.52.1.03.

Dimou, M., Thrasyvoulou, A., Tsirakoglou, V. (2006) Efficient use of pollen traps to determine the pollen flora used by honey bees. J. Apicult. Res. and Bee World. 45(1), 42-46

Dimou, M., Thrasyvoulo, A. (2007) A comparison of three methods for assessing the relative abundance of pollen resources collected by honey bee colonies. J. Apicult. Res. and Bee World. 46(3), 144-148

Eckert, C.D. (1933) The flight range of the honeybee. J. Agric Res. 47(5), 257-286

Eckert, J.E. (1942) The pollen required by a colony of honeybees. J. Econ. Ent. 35(3), 309-311

Eckert, C.D., Winston, M.L., Ydenberg, R.C. (1994) The relationship between population size, amount of brood, and individual foraging behaviour in the honey bee, Apis mellifera L. Oecologia. 97, 248-255

Fahrenholz, L., Lamprecht, I., Schricker, B. (1992) Calorimetric investigations of the different castes of honey bees, Apis mellifera carnica. J. Comp. Physiol. B. 162, 119-130

Fahrenholz, L., Lamprecht, I., Schricker, B. (1989) Thermal investigations of a honey bee colony: thermoregulation of the hive during summer and winter and heat production of members of different bee castes. J. Comp. Physiol. B. 159, 551-560 
Fernandez, P.C., Farina, W.M. (2005) Collective nectar foraging at low reward conditions in honeybees Apis mellifera. Apidologie, 36(3), 301-311

Feuerbacher, E., Fewell, J.H., Roberts, S.P., Smith, E.F., Harrison, J.F. (2003) Effects of load type (pollen or nectar) and load mass on hovering metabolic rate and mechanical power output in the honey bee Apis mellifera. J. Exp. Biol. 206, 1855-1865

Flottum, K. (2014) The Backyard Beekeeper: An Absolute Beginner's Guide to Keeping Bees in Your Yard and Garden, 3rd Edition. Quarryside Publishing Group, Beverly, MA

Forcone, A., Aloisi, P.V., Ruppel, S., Munoz, M. (2011) Botanical composition and protein content of pollen collected by Apis mellifera L. in the north-west of Santa Cruz (Argentinean Patagonia). Grana. 50(1), 30-39

Free, J.B., Spencer-Booth, Y. (1958) Observations on the temperature regulation and food consumption of honeybees (Apis Mellifera). J. Exp. B. 35, 930-937

Furgala, B., McCutcheon, D.M. (1992) Wintering productive colonies. In: The hive and the honeybee, Revised edition. J. M. Graham, ed. Hamilton, IL. Dadant \& Sons, 829-868

Garbuzov, M., Couvillon, M.J., Schurch, R., Ratnieks, F.L.W. (2015) Honey bee dance decoding and pollenload analysis show limited foraging on springflowering oilseed rape, a potential source of neonicotinoid contamination. Agr. Ecosyst. Environ. 203, 62-68

Garcia-Garcia, M., Ortiz, P., Dapena, M. J. D. (2001) Pollen collecting behaviour of Apis mellifera during one day. Grana. 40(4-5), 205-209

Gmeinbauer, R., Crailsheim, K. (1993) Glucose utilization during flight of honeybee (Apis mellifera) workers, drones and queens. J. Insect. Physiol. 39(11), 959-967

Hagler, J.R., Mueller, S., Teuber, L.R., Machtley, S.A., Van Deynze, A. (2011) Foraging Range of Honey Bees, Apis mellifera, in Alfalfa Seed Production Fields. J. Insect. Sci. II, 144

Harano, K., Nakamura, J. (2016) Nectar loads as fuel for collecting nectar and pollen in honeybees: adjustment by sugar concentration. J. Comp. Physiol. 202, 435-443

Harano, K., Sasaki, M. (2015) Adjustment of honey load by honeybee pollen foragers departing from the hive: the effect of pollen load size. Insect. Soc. 62, 497-505

Harano, K., Mitsuhata-Asai, A., Konishi, T., Suzuki, T., Sasaki, M. (2013) Honeybee foragers adjust crop contents before leaving the hive. Behav. Ecol. Sociobiol. 67, 1169-1178

Hartfelder, K., Bitondi, M.M.G., Brent, C.S., GuidugliLazzarini, K.R., Simoes, Z.L.P., Stabentheiner, A., Tanaka, E.D., Wang, Y. (2013) Standard methods for physiology and biochemistry research in Apis mellifera. J. Apicult. Res. 52(1). https://doi. org/10.3896/IBRA.1.52.1.06

Haydak, M.H. (1934) Changes in total nitrogen content during the life of the imago of the worker honeybee. J. Agr. Res. 49(1), 21-28
Haydak, M.H. (1970) Honey bee nutrition. Annu. Rev. Entomol. 15, 143-156

He, X., Wang, W., Qin, Q., Zeng, Z., Zhang, S., Barron, A.B. (2013) Assessment of flight activity and homing ability in Asian and European honey be species, Apis cerana and Apis mellifera, measured with radio frequency tags. Apidologie. 44, 38-51

Heberle, J.A. (1914b) Notes from Germany: How many trips to the field does a bee make in a day? How long does it take to fetch one load? How long does a bee remain in the hive between trips? Glean. Bee Cult. 42(22), 904-905

Herbert, E.W. (1992) Honey Bee Nutrition. The Hive and The Honey Bee, Revised Edition. J. M. Graham. Hamilton, IL. Dadant \& Sons, 197-233

Herbert, E.W., Shimanuki, H. (1982) Effect of population density and available diet on the rate of brood rearing by honey bees offered a pollen substitute. Apidologie. 13, 21-28

Herbert, E.W., Vanderslice, J.T., Higgs, D. J. (1985) Effect of dietary vitamin $\mathrm{C}$ levels on the rate of brood production of free flying and confined colonies of honey bees. Apidologie. 16, 385-394

Herbert, E.W., Sylvester, H.A., Vandenberg, J.D., Shimanuki, H. (1988) Influence of nutritional stress and the age of adults on the morphometrics of honey bees (Apis mellifera L.), Apidologie. 19, 221-230; 26, 287-289

Heusner, A., Stussi, T. (1964) Métabolisme énergétique de l'abeille isolée: Son role dans la thermorégulation de la ruche. Insect Soc. 11(3), 239-266

Huang, M.H., Seeley, T.D. (2003) Multiple unloadings by nectar foragers in honey bees: a matter of information improvement or crop fullness? Insect Soc. 50(4), 330-339

Human, H., Brodschneider, R., Dietemann, V., Dively, G., Ellis, J.D., et al. (2013) Miscellaneous standard methods for Apis mellifera research. In Dietemann, V., Ellis, J. D., Neumann, P. (Eds) COLOSS BEEBOOK, Volume I: standard methods for Apis mellifera research. J. Apicul. Res. 52(4). https://doi. org/10.3896/IBRA.1.52.4.10

Ismail, A.-H.M., Owayss, A.A., Mohanny, K.M., Salem, R.A. (2013) Evaluation of pollen collected by honey bee, Apis mellifera L. colonies at Fayoum Governorate, Egypt. Part 1: Botanical origin. J. Saudi Soc. Agricul. Sci. 12, 129-135

Jeffree, E.P., Allen, M.D. (1957) The annual cycle of pollen storage by honey bees. J. of Econ. Entomol. 50(2), 211-212

Kaiser, W. (1988) Busy bees need rest, too. J. Comp. Physiol. A. 163, 565-584

Knopper, L.D., Dan, T., Reisiq, D.D., Johnson, J.D., Bowers, L.M. (2016) Sugar concentration in nectar: a quantitative metric of crop attractiveness for refined pollinator risk assessments. Pest. Manag. Sci. 72(10), 1807-1812

Kovac, H., Käfer, H., Stabentheiner, A., Costa, C. (2014) Metabolism and upper thermal limits of Apis mellifera carnica and A. m. ligustica. Apidologie. 45, 664-677 
Kumar, R., Agrawal, O.P. (2014) Comparative collection of natural pollen by honey bees in Gwalior \& Panchkula (India). Indian. J. Res. 23(8), 198-199

Liao, C-h., Wu, J., W, Z-1., Wang, Z., Wu, X-b. (2017) Effect of fenpropathrin on the viability and homing ability of worker bees Apis mellifera. J. Asia-Pac. Entomol. 20, 1063-1066

McLellan, A. R. (1976) Factors affecting pollen harvesting by the honeybee. J. Appl. Ecol. 13(3), 801-811

Michener, C. D. (1974) The social behavior of the bees: a comparative study. Harvard University Press, Cambridge, MA

Moffatt, L. (2000) Changes in the metabolic rate of the foraging honeybee: effect of the carried weight or of the reward rate? J. Comp. Physiol. A. 186, 299-306

Moffatt, L., Núñez, J.A. (1997) Oxygen consumption in the foraging honeybee depends on the reward rate at the food source. J. Comp. Physiol. B. 167, 36-42

Moore, D., Siegfried, D., Wilson, R., Rankin, M.A. (1989) The influence of time of day on the foraging behavior of the honeybee, Apis mellifera. J. Biol. Rhythms. 4(3), 305-325

Moore, D., Angel, J. E., Cheeseman, I.M., Fahrbach, S.E., Robinson, G.E. (1998) Timekeeping in the honey bee colony: integration of circadian rhythms and division of labour. Behav. Ecol. Sociobiol. 43, 147-160

Nachtigall, W., Rothe, U., Feller, P., Jungmann, R. (1989) Flight of the honey bee. III. Flight metabolic power calculated from gas analysis, thermoregulation and fuel consumption. J. Comp. Physiol. B. 158, 729-737

Nicolson, S.W., de Veer, L., Köhler, A., Pirk, C.W.W. (2013) Honeybees prefer warmer nectar and less viscous nectar, regardless of sugar concentration. Proceedings of the Royal Society B. 280, 20131597. https://doi.org/10.1098/rspb.2013.1597

Núñez, J.A. (1970) The relationship between sugar flow and foraging and recruiting behaviour of honey bees (Apis mellifera L.). Anim. Behav. 18, 527-538

Núñez, J.A., Giurfa, M. (1996) Motivation and regulation of honey bee foraging. Bee World. 77(4) 182-196

Odoux, J.F., Feuillet, D., Aupinel, D., Loublier, P., Tasei, Y., Mateescu, J.N. (2012) Territorial biodiversity and consequences on physico-chemical characteristics of pollen collected by honey bee colonies. Apidologie. 43(5), 561-575

O'Neal, R., Waller, G.D. (1984) On the Pollen Harvest by the Honey Bee (Apis mellifera L.) Near Tucson, Arizona (1976-1981). Desert Plants. 6(2), 81-110

Pacini, E., Nicolson, S.W. (2007) Introduction, in Nectaries and Nectar, S.W. Nicolson, M. Nepi E. Pacini, eds. Springer, Dordrecht, The Netherlands

Pankiw, T., Nelson, M., Page, R.E., Fondrk, M.K. (2004) The communal crop: modulation of sucrose response thresholds of pre-foraging honey bees with incoming nectar quality. Behav. Ecol. Sociobiol. 55, 286-292

Perry, C.J., Søvik, E., Myerscough, M.R., Barron, A.B. (2015) Rapid behavioral maturation accelerates failure of stressed honey bee colonies. PNAS. 113(30), 34273432

Prado, A., Pioz, M., Vidau, C., Requier, F., Jury, M., Crauser, D., Brunet, J.-L., Le Conte, Y., Alaux, C. (2019) Exposure to pollen-bound pesticide mixtures induces longer-lived but less efficient honey bees. Science of the Total Environment. 650, 1250-1260

Rashad, S.E.-D., Parker, R.L. (1958) Pollen as a limiting factor in brood rearing and honey production during three drought years, 1954, 1955, and 1956. Transaction of the Kansas Academy of Science. 61(3), 237-248

Requirer, F., Odoux, J.F., Tamic, T., Moreau, N., Henry, M., Decourtye, A., Bretagnolle, V. (2015) Honey bee diet in intensive farmland habitats reveals an unexpectedly high flower richness and a major role of weeds. Ecol. Appl. 25(4), 881-890

Ribbands, C.R. (1949) The foraging method of individual honey-bees. J. Anim. Ecol. 18(1), 47-66

Ribbands, C.R. (1953) The behaviour and social life of honeybees. London, Bee Research Association. Dover, NY

Riley, J.R., Greggers, U., Smith, A.D., Reynolds, D.R., Menzel, R. (2005) The flight paths of honeybees recruited by the waggle dance. Nature. 435, 205-207

Roberts, S.P., Harrison, J.F. (1999) Mechanisms of thermal stability during flight in the honeybee Apis mellifera. J. Exp. Biol. 202, 1523-1533

Rodney, S., Kramer, V. (2019) Probabilistic assessment of nectar requirements for nectar-foraging honey bees. Apidologie. https://doi.org/10.1007/s13592-019-00693-w

Schmickl, T., Karsai, I. (2016) How regulation based on a common stomach leads to economic optimization of honeybee foraging. J. Theor. Biol. 389, 274-286

Schmid-Hempel, P. (1987) Efficient nectar-collecting by honeybees I. economic models. J. Anim. Ecol. 56(1), 209-218

Schmid-Hempel, P., Kacelnik, A., Houston, A.I. (1985) Honeybees maximize efficiency by not filling their crop. Behav. Ecol. Sociobiol. 17, 61-66

Schmidt, J.O., Buchmann, S.I. (1985) Pollen digestion and nitrogen utilization by Apis mellifera L. (Hymenoptera: Apidae). Comp. Biochem. Physiol. 82A(3), 499503

Seeley, T.D. (1996) The Wisdom of the Hive: The Social Physiology of Honey Bee Colonies. Harvard University Press, Cambridge, MA

Seeley, T.D., Visscher, K. (1985) Survival of honeybees in cold climates: the critical timing of colony growth and reproduction. Econ. Entomol. 10, 81-88

Seeley, T.D., Camazine, S., Sneyd, J. (1991) Collective decision-making in honey bees: how colonies choose among nectar sources. Behav. Ecol. Sociobiol. 28, 277-290

Schmolz, E., Hoffmeister, D., Lamprecht, I. (2002) Calorimetric investigations on metabolic rates and thermoregulation of sleeping honeybees (Apis mellifera carnica).

Soehngen, U., Jay, S.C. (1973) Studies on the Honey-Sac Contents and Pollen Loads of Honeybees 1. Honey- 
Sac Contents of Bees in the Hive. J. Apicult. Res. 12(2), 65-73

Soehngen, U., Jay, S.C. (1974) Studies on the honey-sac contents and pollen loads of honeybees 2. Honey-sac contents of foraging bees. J. Apicul. Res. 13(3), 199206

Southwick, E.E., Pimentel, D. (1981) Energy efficiency of honey production by bees. BioScience. 31(10), 730732

Stabentheiner, A., Kovac, H., Hetz, S.K., Käfer, H., Stabentheiner, G. (2012) Assessing honeybee and wasp thermoregulation and energetics - new insights by combination of flow-through respirometry with infrared thermography. Thermochimica acta. 534, 77-86

Stabentheiner, A., Kovac, H. (2016) Honeybee economics: optimisation of foraging in a variable world. Scientific Reports 6(28339). https://doi.org/10.1038/srep28339

Stabentheiner, A., Pressl, H., Papst, T., Hrassnigg, N., Crailsheim, K. (2003a) Endothermic heat production in honey bee winter clusters. J. Exp. Biol. 206, 353358

Stabentheiner, A., Vollmann, J., Kovac, H., Crailsheim, K. (2003b) Oxygen consumption and body temperature of active and resting honeybees. J. Insect. Physiol. 49, 881-889

Steffan-Dewenter, I., Kuhn, A. (2003) Honeybee foraging in differentially structured landscapes. Proc. R. Soc. Lond. B. 270, 569-575

Tenczar, P., Lutza, C.C., Rao, V.D., Goldenfeld, N., Robinson, G.E. (2014) Automated monitoring reveals extreme inter-individual variation and plasticity in honeybee foraging activity levels. Anim. Behav. 95, 41-48

Thenius, R., Schmickl, T., Crailsheim, K. (2008) Optimization of a honeybee-colony's energetics via social learning based on queuing delays. Connect. Sci. 20(2-3), 193-210

Thom, C., Seeley, T.D., Tautz, J. (2000) A scientific note on the dynamics of labor devoted to nectar foraging in a honey bee colony: number of foragers versus individual foraging activity. Apidologie. 31(6), 737-738

Thompson, H., Coulson, M., Ruddle, N., Wilkins, S., Harkin, S. (2016) Thiamethoxam: assessing flight activity of honeybees foraging on treated oilseed rape using radio frequency identification technology. Environ. Toxicol. Chem. 35(2), 385-393

Tian, L.-Q., Xu-jiang, H., Bo Wu, X., Gan, H.-Y., Han, X., Liu, H., Zeng, Z.-J. (2014) Study on foraging behaviors of honeybee Apis mellifera based on RFID technology. Chinese J. Appl. Ecol. 25(3), 831-835. Article in Chinese, abstract in English.

Tomlinson, S., Dixon, K.W., Didham, R.K., Bradshaw, S.D. (2015) Physiological plasticity of metabolic rates in the invasive honey bee and an endemic Australian bee species. J. Comp. Physiol. B. 185, 835-844
Tomlinson, S., Dixon, K.W., Didham, R.K., Bradshaw, S.D. (2017) Landscape context alters cost of living in honeybee metabolism and feeding. Proc. R. Soc. B. 284, 20162676.

USDA (US Department of Agriculture) (2016) Guidance on Exposure and Effects Testing for Assessing Risks to Bees. Office of Pesticide Programs U.S. Environmental Protection Agency, 2016

USEPA (US Environmental Protection Agency) (1998) Guidelines for Ecological Risk Assessment. Office of Research and Development, Washington, DC. EPA/ 630/R- 95/002F

USEPA (US Environmental Protection Agency) (2011) Interim Guidance on Honey Bee Data Requirements. Environmental Fate and Effects Division, Office of Pesticide Programs

USEPA (US Environmental Protection Agency), PMRA (Pest Management Regulatory Agency) and CDPR (California Department of Pesticide Regulation) (2012) White Paper in Support of the Proposed Risk Assessment Process for Bees. Submitted to the FIFRA Scientific Advisory Panel for Review and Comment, September $11-14,2012$. Office of Chemical Safety and Pollution Prevention (US Environmental Protection Agency), Pest Management Regulatory Agency (PMRA) Health Canada, and California Department of Pesticide Regulation (CDPR)

USEPA (US Environmental Protection Agency), PMRA (Pest Management Regulatory Agency) and CDPR (California Department of Pesticide Regulation) (2014) Guidance for Assessing Pesticide Risks to Bees

van der Steen, J. (2015) The foraging honey bee. The British Bee Journal. February, 43-46

van der Steen, J.J.M., Cornelissen, B., Donders, J., Blacquière, T., van Dooremalen, C. (2012) How honey bees of successive age classes are distributed over a one storey, ten frames hive. J. Apicult. Res. 51(2), 174-178

Visscher, P.K., Seeley, T.D. (1982) Foraging strategy of honeybee colonies in a temperate deciduous forest. Ecol. 63(6), 1790-1801

Visscher, P.K., Crailsheim, K., Sherman, G. (1996) How do honeybees (Apis mellifera) fuel their water foraging flights? J. Insect Physiol. 42, 1089-1094

Wilde, J., Paleolog, J., Grabowski, P., Siuda, M., Bratkowski, J. (2011) Correlated and direct responses to selection of high and low pollen yield in a small, open population of Apis mellifera carnica. J Apicult. Res. 50(3), 181-189

Withers, P.C. (1981) The effects if ambient air pressure on oxygen consumption of resting and hovering honeybees. J. Comp. Physiol. 141, 433-437

Winston, M.L. (1987) The Biology of the Honey Bee. Harvard University Press. Cambridge, MA

Wolf, T.J., Schmid-Hempel, P., Ellington, C.P., Stevenson, R.D. (1989) Physiological correlates of foraging efforts in honey-bees: Oxygen consumption and nectar load. Funct.. Ecol. 3(4), 417-424 
Woods, W.A.J., Heinrich, B., Stevenson, R.D. (2005) Honeybee flight metabolic rate: does it depend upon air temperature? J. Exp. Biol. 208, 11611173

Worswick, P.V.W. (1988) Comparison of nectar foraging efficiency in the Cape honeybee, Apis mellifera capensis Escholtz, and the African honeybee, Apis mellifera adansonii Latreille, in the western Cape Province. S. Afr. J. Zool. 23(2), 124-127

Publisher's note Springer Nature remains neutral with regard to jurisdictional claims in published maps and institutional affiliations. 